\title{
Alteration of Electron Acceptor Preferences in the Oxidative Half-Reaction of Flavin-Dependent Oxidases and Dehydrogenases
}

\author{
Kentaro Hiraka ${ }^{1}$, Wakako Tsugawa ${ }^{1}(1)$ and Koji Sode ${ }^{2, *}$ \\ 1 Department of Biotechnology and Life Science, Graduate School of Engineering, Tokyo University of \\ Agriculture and Technology, 2-24-16 Naka-cho, Koganei, Tokyo 184-8588, Japan; \\ s189868s@st.go.tuat.ac.jp (K.H.); tsugawa@cc.tuat.ac.jp (W.T.) \\ 2 Joint Department of Biomedical Engineering, The University of North Carolina at Chapel Hill and North \\ Carolina State University, Chapel Hill, NC 27599, USA \\ * Correspondence: ksode@email.unc.edu; Tel.: +1-919-966-3550
}

Received: 5 May 2020; Accepted: 24 May 2020; Published: 27 May 2020

\begin{abstract}
In this review, recent progress in the engineering of the oxidative half-reaction of flavin-dependent oxidases and dehydrogenases is discussed, considering their current and future applications in bioelectrochemical studies, such as for the development of biosensors and biofuel cells. There have been two approaches in the studies of oxidative half-reaction: engineering of the oxidative half-reaction with oxygen, and engineering of the preference for artificial electron acceptors. The challenges for engineering oxidative half-reactions with oxygen are further categorized into the following approaches: (1) mutation to the putative residues that compose the cavity where oxygen may be located, (2) investigation of the vicinities where the reaction with oxygen may take place, and (3) investigation of possible oxygen access routes to the isoalloxazine ring. Among these approaches, introducing a mutation at the oxygen access route to the isoalloxazine ring represents the most versatile and effective strategy. Studies to engineer the preference of artificial electron acceptors are categorized into three different approaches: (1) engineering of the charge at the residues around the substrate entrance, (2) engineering of a cavity in the vicinity of flavin, and (3) decreasing the glycosylation degree of enzymes. Among these approaches, altering the charge in the vicinity where the electron acceptor may be accessed will be most relevant.
\end{abstract}

Keywords: oxidase; dehydrogenase; oxidative half-reaction; oxygen; electron acceptor; flavin adenine dinucleotide; flavin mononucleotide; oxygen accessible pathway; bioelectrochemistry; enzyme engineering

\section{Introduction}

Oxidation reactions catalyzed by flavin-dependent oxidoreductases are widely used in areas such as the life sciences, chemistry, and industry. Flavin can receive two electrons from oxidizing substrates and release electrons to external electron acceptors in the oxidation reaction of flavin-dependent enzymes. Flavin-dependent oxidoreductases can be divided into oxidases, dehydrogenases, monooxygenases, halogenases, and so on [1]. Flavin-dependent oxidases and dehydrogenase based oxidation reactions, as well as their structural-function relationships, have been studied well in recent decades. Flavin-dependent oxidases oxidize substrates with the reduction of flavin (reductive half-reaction), and the reduced flavin is reoxidized by oxygen, liberating hydrogen peroxide (oxidative half-reaction). Flavin-dependent oxidases also utilize a variety of artificial electron acceptors instead of oxygen. The artificial electron acceptors refer to chemically synthesized redox active compounds, including organic, inorganic, and metal-organic compounds. A review article by Heller and Feldman 
well summarized the variation of artificial electron acceptors, by introducing them for glucose oxidoreductases [2]. However, in flavin-dependent oxidases, artificial electron acceptors compete with oxygen during the oxidative-half reaction [3-5]. Flavin-dependent dehydrogenases proceed with the same reductive half-reaction as that of oxidase, but they do not utilize oxygen as an electron acceptor in the oxidative half-reaction; instead, they use a variety of electron acceptors, including artificial electron acceptors [6,7].

In addition to the basic studies of reaction mechanisms, flavin-dependent oxidases and dehydrogenases have been utilized as molecular recognition elements of biosensors and biofuel cells in the electrochemical field. The first enzyme-based amperometric biosensor was reported in 1962 by Clark and Lyons using a combination of glucose oxidase and oxygen electrodes [8]. In the same year, the first enzymatic biofuel cell was also reported by Davis and Yarbrough using glucose oxidase as an anodic element [9]. Since then, many enzyme-based biosensors or biofuel cells have been developed [10,11]. After years of effort, flavin-dependent oxidoreductases, which include flavin mononucleotide (FMN)and flavin adenine dinucleotide (FAD)-dependent oxidases and dehydrogenases, have been widely used to construct bioelectrochemical reaction based-biosensors and biofuel cells. Flavin-dependent oxidase-based biosensors detect the consumption of dissolved oxygen or the liberation of hydrogen peroxide depending on the substrate concentration, which is designated as the first-generation principle for electrochemical enzyme sensors [12]. However, dissolved oxygen fluctuation causes bias errors in the first-generation sensing system [13]. Further, a high applied potential for oxidizing hydrogen peroxide is required, which causes another bias error from the oxidation of interferents, such as ascorbic acid [14]. In addition, hydrogen peroxide potentially damages the electrode surface and the enzymes $[15,16]$. To overcome the inherent drawback of flavin-dependent oxidases, the use of artificial electron acceptors as electron mediators between the enzymes and the electrode has become popular, and the principle is designated as the second-generation principle, which was first reported in 1984 [14]. Moreover, various dehydrogenases have been utilized in second-generation principle-based sensors. However, the limited availability of flavin-dependent dehydrogenases is the key issue for the further development of second-generation enzyme sensors. The use of artificial electron acceptors with low oxidation potential helps to avoid the signals from redox active interferents during the measurements [2]. Considering the chemical stability, solubility, and redox potential, several electron acceptors were used to construct second-generation enzyme sensors using flavin-dependent oxidases and dehydrogenases [2,17]. However, each flavin-dependent oxidase or dehydrogenase has a preference for certain electron acceptors, and therefore, the improvement of specificities toward these mediators is in great demand $[18,19]$.

In this review, recent progress in the investigation/engineering of the oxidative half-reaction of flavin-dependent oxidases and dehydrogenases is summarized and discussed, considering their current and future applications in bioelectrochemical studies, such as for the developments of biosensors and biofuel cells. These studies are categorized into two approaches: engineering of the oxidative half-reaction with oxygen, and engineering with the preference for artificial electron acceptors.

\section{Engineering of the Oxidative Half-Reaction with Oxygen}

Figure 1A explains the reaction scheme of the oxidases with molecular oxygen [20]. The reduced flavin transfers one electron to molecular oxygen to form a radical pair at isoalloxazine C4a in the first step. In the second step, another electron is transferred from isoalloxazine N5, or a protonated catalytic residue rapidly generates hydrogen peroxide and oxidized flavin [20,21]. The formation of (C4a)-hydroperoxy flavin was the common reaction intermediate in the oxidative half-reaction of flavin-dependent monooxygenases [1]. Except in some cases [22,23], this intermediate formation was not detected in flavin-dependent oxidases due to its rapid collapse, but it was considered a possible reaction intermediate [22]. The difference in the stability of this intermediate between oxidases and monooxygenases well explains the difference of the product formations in their oxidative half-reaction: hydrogen peroxide formation in oxidases, and inserting an oxygen atom into a substrate 
in monooxygenases $[1,24]$. Namely, the isoalloxazine C4a atom and its surrounding environment contributes to the reaction between oxygen and flavin, therefore, introducing mutations in the amino acid residues existing in this region are the representative rational strategy to engineer the oxidative half-reaction with oxygen in the flavin-dependent oxidases. However, it remains to be elucidated why and how "oxidases" can use oxygen as the primary electron acceptor in flavin-dependent oxidases, whereas "dehydrogenases" cannot, even though both oxidases and dehydrogenases proceed through identical reductive half-reactions with similar overall structures (e.g., glucose oxidase and glucose dehydrogenase) [25].

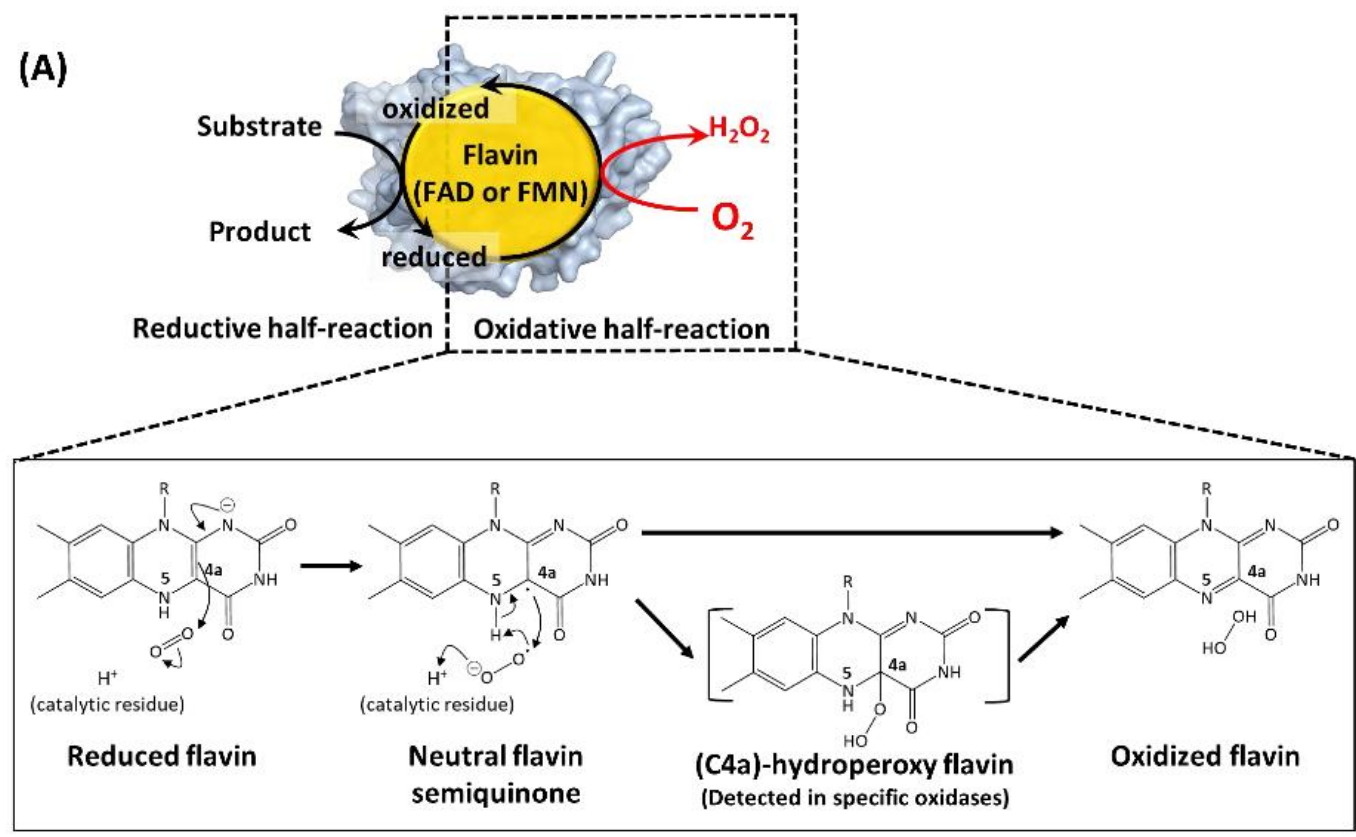

(B)

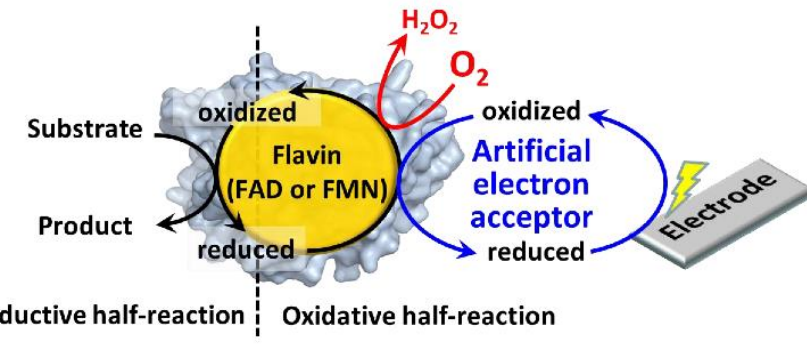

(C)

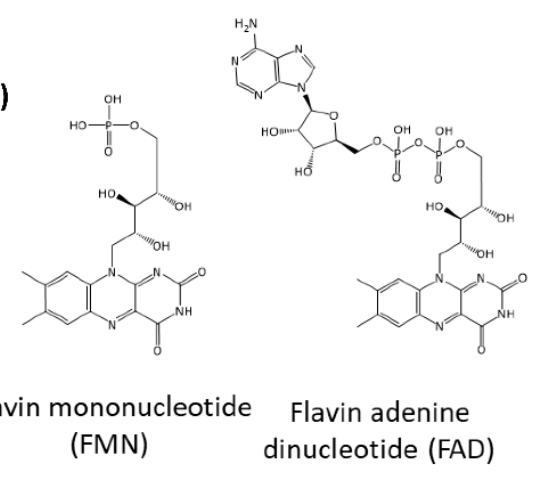

Figure 1. (A) Reaction scheme of a flavin-dependent oxidase with molecular oxygen [20]. (B) Reaction scheme of a flavin-dependent oxidase or dehydrogenase with an artificial electron acceptor. Oxidases react with oxygen, as shown by the red arrow and character. Both oxidases and dehydrogenases react with artificial electron acceptors as electron mediators between enzymes and electrodes. (C) Flavin mononucleotide (FMN) and flavin adenine dinucleotide (FAD) structural formulas. 
Pioneering studies reported the creation of "dehydrogenases" from oxidases to solve the inherent problem of oxidase-utilizing enzyme-based assays and electrochemical sensing systems employing artificial electron acceptors, where the competition of oxygen with artificial electron acceptors resulted in inaccurate results (Figure 1B).

Table 1 summarizes the representative studies reporting the investigation and engineering of the oxidative half-reaction of flavin-dependent oxidases and dehydrogenases with oxygen as the electron acceptor. These studies are categorized into three approaches: (1) mutation to the putative residues that compose the cavity where oxygen may be located, (2) investigation of the locations where the reaction with oxygen may take place, and (3) investigation of possible oxygen access routes to the isoalloxazine ring. These twelve oxidases and five dehydrogenases are classified into five enzyme families according to their characteristic structures (Figure 2) [3]. In this classification, four enzyme families are FAD-dependent enzymes and only one enzyme family is FMN-dependent enzymes. Due to the structural difference between FAD and FMN (Figure 1C), FAD-dependent enzymes have glycine rich motifs for binding with the adenine moiety of FAD, but FMN-dependent enzymes do not have a specific motifs for binding with FMN. 
Table 1. The investigation/engineering the oxidative half-reaction of flavin-dependent oxidases and dehydrogenases with oxygen as the electron acceptor.

\begin{tabular}{|c|c|c|c|c|c|c|}
\hline $\begin{array}{l}\text { Enzyme } \\
\text { (Source) }\end{array}$ & $\begin{array}{c}\text { Family } \\
\text { (EC: Number) }\end{array}$ & Co-Factor & Mutation Site & Mutated Position & Effects of Mutation & Reference \\
\hline \multicolumn{7}{|c|}{ (1) Investigation/engineering of the putative residues which are predicted oxygen binding site } \\
\hline $\begin{array}{c}\text { Glucose oxidase } \\
\text { (Penicillium amagasakiense) }\end{array}$ & $\begin{array}{c}\text { GMC } \\
(\text { EC: } 1.1 .3 .16)\end{array}$ & FAD & S114A, F355L & Predicted oxygen binding site & Decreased oxidase activity & {$[26,27]$} \\
\hline $\begin{array}{l}\text { Glucose oxidase } \\
\text { (Aspergillus niger) }\end{array}$ & $\begin{array}{c}\text { GMC } \\
\text { (EC: } 1.1 .3 .16)\end{array}$ & FAD & T110A, F351L & Predicted oxygen binding site & Decreased oxidase activity & [26] \\
\hline $\begin{array}{c}\text { Cholesterol oxidase } \\
\text { (Streptomyces sp. SA-COO) }\end{array}$ & $\begin{array}{c}\text { GMC } \\
\text { (EC: } 1.1 .3 .6) \\
\end{array}$ & FAD & V191A, F359W & $\begin{array}{l}\text { Oxygen binding site of } \\
\text { crystal structure }\end{array}$ & Decreased oxidase activity & {$[28,29]$} \\
\hline \multicolumn{7}{|c|}{ (2) Investigation/engineering of the cavity in vicinity of isoalloxazine ring } \\
\hline $\begin{array}{c}\text { Glucose oxidase } \\
\text { (Penicillium amagasakiense) }\end{array}$ & $\begin{array}{c}\text { GMC } \\
\text { (EC: } 1.1 .3 .16)\end{array}$ & FAD & V564S & Vicinity of FAD & Decreased oxidase activity & [30] \\
\hline $\begin{array}{l}\text { Glucose oxidase } \\
\text { (Aspergillus niger) }\end{array}$ & $\begin{array}{c}\text { GMC } \\
\text { (EC: } 1.1 .3 .16)\end{array}$ & FAD & $\begin{array}{c}\mathrm{V} 560 \mathrm{~T} \\
\text { (random mutation) }\end{array}$ & Vicinity of FAD & Decreased oxidase activity & [31] \\
\hline $\begin{array}{l}\text { Pyranose oxidase } \\
\text { (Trametes multicolor) }\end{array}$ & $\begin{array}{c}\text { GMC } \\
(\text { EC: } 1.1 .3 .10)\end{array}$ & FAD (covalent) & L547R, N593C & Vicinity of FAD & Decreased oxidase activity & {$[32,33]$} \\
\hline $\begin{array}{c}\text { Choline oxidase } \\
\text { (Arthrobacter globiformis) }\end{array}$ & $\begin{array}{c}\text { GMC } \\
\text { (EC: } 1.1 .3 .17)\end{array}$ & FAD (covalent) & V464T, V464A & Vicinity of FAD & Decreased oxidase activity & [34] \\
\hline $\begin{array}{l}\text { Aryl-alcohol oxidase } \\
\text { (Pleurotus eryngii) }\end{array}$ & $\begin{array}{c}\text { GMC } \\
\text { (EC: } 1.1 .3 .7)\end{array}$ & FAD & F501A, F397W & Vicinity of FAD & Decreased oxidase activity & {$[35,36]$} \\
\hline & & & F501W & Vicinity of FAD & Increased oxidase activity & [35] \\
\hline $\begin{array}{l}\text { Fructosyl amino acid oxidase } \\
\text { (Pichia sp. N1-1) }\end{array}$ & $\begin{array}{c}\text { DAO } \\
\text { (EC: } 1.5 .3)\end{array}$ & FAD (covalent) & K276M, N47A & $\begin{array}{l}\text { Proton relay system } \\
\text { (Vicinity of FAD) }\end{array}$ & Decreased oxidase activity & [37] \\
\hline $\begin{array}{l}\text { Fructosyl peptide oxidase } \\
\text { (Phaeosphaeria nodorum) }\end{array}$ & $\begin{array}{l}\text { DAO } \\
\text { (EC: } 1.5 .3)\end{array}$ & FAD (covalent) & N56A & $\begin{array}{l}\text { Proton relay system } \\
\text { (Vicinity of FAD) }\end{array}$ & Decreased oxidase activity & [38] \\
\hline $\begin{array}{l}\text { Monomeric sarcosine oxidase } \\
\quad \text { (Bacillus sp. B-0618) }\end{array}$ & $\begin{array}{c}\text { DAO } \\
(\mathrm{EC}: 1.5 .3 .1)\end{array}$ & FAD (covalent) & K265M & $\begin{array}{l}\text { Proton relay system } \\
\text { (Vicinity of FAD) }\end{array}$ & Decreased oxidase activity & [39] \\
\hline $\begin{array}{l}\text { Berberine bridge enzyme } \\
\text { (Reticuline oxidase) } \\
\text { (Eschscholzia californica) }\end{array}$ & $\begin{array}{c}\mathrm{VAO} \\
\text { (EC: } 1.21 .3 .3)\end{array}$ & FAD (covalent) & G164A, V169I & Vicinity of FAD & Decreased oxidase activity & [40] \\
\hline $\begin{array}{l}\text { Cellobiose dehydrogenase } \\
\text { (Myriococcum thermophilum) }\end{array}$ & $\begin{array}{c}\text { GMC } \\
\text { (EC: } 1.1 .99 .18)\end{array}$ & FAD & N700S & Vicinity of FAD & Increased oxidase activity & [41] \\
\hline $\begin{array}{l}\text { Pyranose dehydrogenase } \\
\text { (Agaricus meleagris) }\end{array}$ & $\begin{array}{c}\text { GMC } \\
(\text { EC: } 1.1 .99 .29)\end{array}$ & FAD (covalent) & H103Y & $\begin{array}{c}\text { Vicinity of FAD } \\
\text { (Covalent bond with FAD) }\end{array}$ & $\begin{array}{l}\text { Breaking of covalent bond } \\
\text { with FAD } \\
\text { Increased oxidase activity }\end{array}$ & [42] \\
\hline
\end{tabular}


Table 1. Cont

\begin{tabular}{|c|c|c|c|c|c|c|}
\hline $\begin{array}{l}\text { Enzyme } \\
\text { (Source) }\end{array}$ & $\begin{array}{c}\text { Family } \\
\text { (EC: Number) }\end{array}$ & Co-Factor & Mutation Site & Mutated Position & Effects of Mutation & Reference \\
\hline $\begin{array}{l}\text { L-Galactono- } \gamma \text {-lactone } \\
\text { dehydrogenase } \\
\text { (Arabidopsis thaliana) }\end{array}$ & $\begin{array}{c}\mathrm{VAO} \\
(\mathrm{EC}: 1.3 .2 .3)\end{array}$ & FAD (covalent) & A113G & Vicinity of FAD & Increased oxidase reactivity & [43] \\
\hline $\begin{array}{l}\text { Pollen allergen } \mathrm{Phl} \mathrm{p} 4 \\
\quad \text { (Phleum pretense) }\end{array}$ & $\begin{array}{l}\text { VAO } \\
(\mathrm{EC}:-)\end{array}$ & FAD (covalent) & I153V & Vicinity of FAD & Increased oxidase activity & [40] \\
\hline $\begin{array}{c}\text { (2S)-methylsuccinyl-CoA } \\
\text { dehydrogenase } \\
\text { (Rhodobacter sphaeroides) }\end{array}$ & $\begin{array}{c}\mathrm{ACO} \\
(\mathrm{EC}: 1.3 .8 .12)\end{array}$ & FAD & W315F/T317G/E377N & Vicinity of FAD & Increased oxidase activity & {$[44,45]$} \\
\hline \multicolumn{7}{|c|}{ (3) Investigation/engineering of possible oxygen access route from external enzyme to the isoalloxazine ring } \\
\hline $\begin{array}{l}\text { Choline oxidase } \\
\text { (Arthrobacter globiformis) }\end{array}$ & $\begin{array}{c}\text { GMC } \\
\text { (EC: } 1.1 .3 .17)\end{array}$ & FAD (covalent) & F357A & $\begin{array}{c}\text { Predicted oxygen accessible } \\
\text { pathway }\end{array}$ & Decreased oxidase activity & [46] \\
\hline $\begin{array}{l}\text { D-amino acid oxidase } \\
\text { (Rhodotorula gracilis) }\end{array}$ & $\begin{array}{c}\mathrm{DAO} \\
(\mathrm{EC}: 1.4 .3 .3)\end{array}$ & FAD & G52V & $\begin{array}{c}\text { Predicted oxygen accessible } \\
\text { pathway }\end{array}$ & Decreased oxidase activity & [47] \\
\hline $\begin{array}{l}\text { L-lactate oxidase } \\
\text { (Aerococcus viridans) }\end{array}$ & $\begin{array}{c}\text { HAO } \\
\text { (EC: } 1.1 .3 .15)\end{array}$ & FMN & $\begin{array}{l}\text { A96L, N212K, } \\
\text { A96L/N212K }\end{array}$ & $\begin{array}{c}\text { Predicted oxygen accessible } \\
\text { pathway }\end{array}$ & Decreased oxidase activity & {$[48,49]$} \\
\hline
\end{tabular}



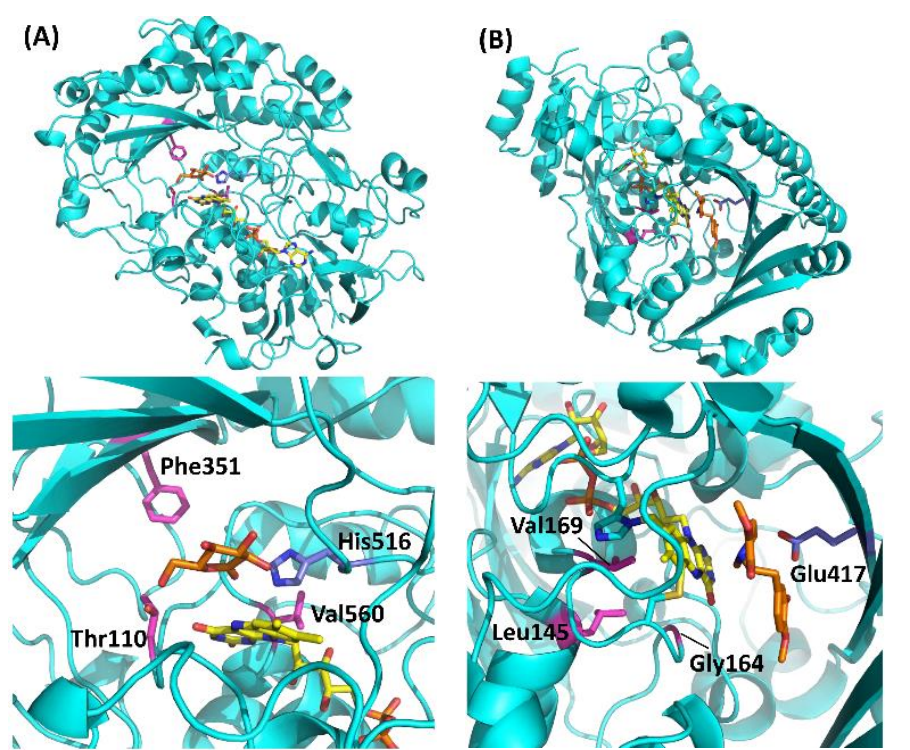

(C)
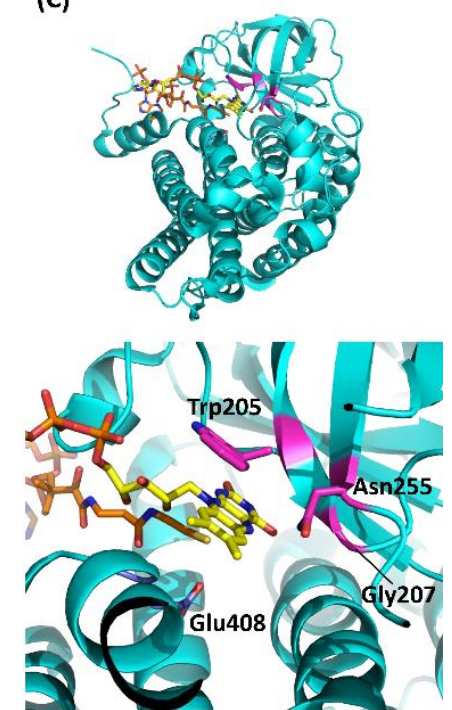

(D)


(E)
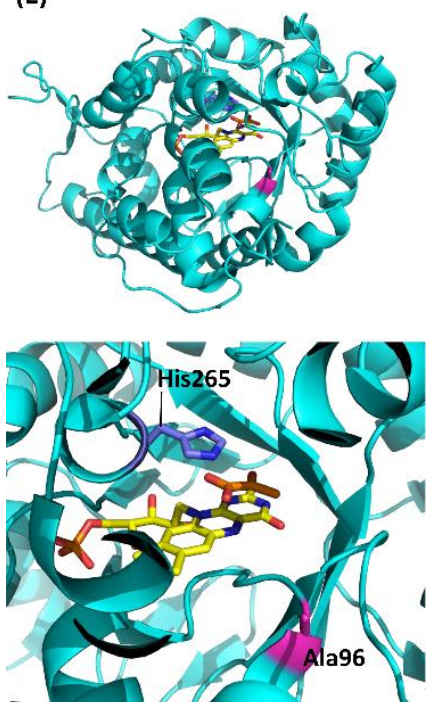

Figure 2. Representative flavin-dependent oxidase/dehydrogenase family enzyme structures. (A) AnGOx (PDB code: 1CF3), GMC family; (B) BBE (PDB code: 3D2D), VAO family; (C) Short-chain specific acyl-CoA oxidase (PDB code: 2IX5), ACO family; (D) DAO (PDB code: 1C0I), DAO family; (E) AvLOx (PDB code: 2E77), HAO family. The upper figures show the whole structure, and the lower figures show the flavin vicinity. Flavins are colored yellow, and substrate analogs are shown in orange. Purple amino acid residues are catalytic residues, and magenta residues are important residues for reactivity against oxygen. Gluconolactone in (A) was visualized by superimposition with AfGDH (PDB code: 4 YNU) due to the high similarity (RMSD $=0.934 \AA$ ). Structure visualization was conducted using the PyMOL Molecular Graphics System, Version 2.2.3 Schrödinger, LLC. 
The first category focuses on the putative residues that are predicted to compose the cavity where oxygen may be located [26-29]. A sub-atomic resolution crystal structure of FAD-dependent cholesterol oxidase (ChOx) from Streptomyces sp. SA-COO was reported by Lario et al., providing a ChOx structure with a dioxygen molecule that was modeled in the active site [50]. Phe359, which is located proximate to the modeled oxygen molecule showed two conformations and opened or closed a hydrophobic tunnel from the external enzyme to the FAD vicinity depending on the Phe359 side chain orientation (Figure 3A,B). As the Phe359Trp mutant showed a drastic decrease in reactivity for oxygen, this hydrophobic tunnel was considered an oxygen-accessible pathway from an external enzyme to FAD [28]. However, the dye-mediated dehydrogenase activity of the Phe359Trp mutant was not investigated, and we could not know whether this mutation caused inactivation of the oxidative half-reaction. To reduce the reactivity for oxygen without loss of the dye-mediated dehydrogenase activity of ChOx, Kojima et al. reported mutations in amino acid residues that constitute the cavity where oxygen may interact, including Phe359 [29]. As a result, the Val191Ala mutant showed drastically low oxidase activity and increased dye-mediated dehydrogenase activity. Horaguchi et al. compared the active site structures of glucose oxidases (GOxs) and ChOx, considering that both oxidases are members of the glucose/methanol/choline (GMC) oxidoreductase family [26,27]. From the superposition of these structures, the putative cavity where oxygen may interact was predicted for GOx from Penicillium amagasakiense (PaGOx) and Aspergillus niger (AnGOx) (Figure 3C,D). Consequently, the PaGOx Ser114Ala and Phe355Leu, and AnGOx Thr110Ala and Phe351Leu mutations resulted in decreased oxidase activity when measuring hydrogen peroxide liberation, whereas the dye-mediated dehydrogenase activity increased. An enzyme electrode with a PaGOx Ser114Ala/Phe355Leu double mutant was constructed, and the impact of the presence or absence of oxygen during electron mediator-type enzyme sensor operation was investigated by comparing the electrode with wild-type PaGOx. The results revealed that the enzyme sensor with the PaGOx Ser114Ala/Phe355Leu double mutant showed a minimized impact of oxygen during measurement, specifically at a lower glucose concentration [27]. These results also suggested that GMC oxidoreductase family enzymes may have substrate- and oxygen-accessible tunnels, which are located on the Re-side of the isoalloxazine ring of flavin (Figure 2A).

The second category focuses on a cavity in the vicinity of the isoalloxazine ring [30-45]. Considering the reaction between oxygen and flavin, the region is likely crucial for the oxidative half-reaction. Based on crystal structural analyses, most of the approaches aimed to alter the oxidative half-reaction by mutating amino acid residues located near isoalloxazine ring C4a. Among them, Zafred et al. reported the study of oxygen reactivity in the vanillyl alcohol oxidase (VAO) superfamily by using the berberine bridge enzyme (BBE) and the BBE-like protein, pollen allergen Phl p 4, as models, showing that steric control of access to this site was the most important parameter affecting dioxygen reactivity in BBE-like enzymes [40]. BBE from Eschsholzia californica is (S)-reticuline oxidase, which is a member of the VAO superfamily, and Phl p 4 from Phleum pratense is also a VAO superfamily enzyme. BBE catalyzes (S)-reticuline oxidation with oxygen as a primary electron acceptor, but Phl p 4 catalyzes glucose oxidation without oxygen as an electron acceptor. BBE and Phl p 4 have similar structures, but the reactivity for oxygen is completely different. They focused on a difference in the cavity size in front of isoalloxazine C4a. BBE has a larger cavity than Phl p 4 in front of the FAD C4a, consisting of Gly164, Val169, and His174; but Phl p 4 has a smaller cavity than BBE, consisting of Gly148, Ile153, and Asn158. As a result of mutagenesis studies, the BBE Gly164Ala mutant showed a drastic decrease in the reaction rate constants with oxygen in the oxidative half-reaction $\left(k_{\mathrm{ox}}\right)$, but the Phl p 4 Ile153Val mutant was increased by the $k_{\mathrm{ox}}$ value despite no change in the reaction rate constants for each substrate in the reductive half-reaction $\left(k_{\text {red }}\right)$. These mutations did not affect the redox potentials of these enzymes. Therefore, engineering of the cavity in front of isoalloxazine C4a enables control of the reactivity for oxygen. This report also revealed that substrates of VAO family enzymes come from the Si-side of the isoalloxazine ring, but an oxygen reaction occurred on the Re-side (Figure 2B). This reaction system is different from that of GMC oxidoreductase family enzymes. 



Figure 3. Amino acid residues composing the cavity where oxygen may be located in (A) ChOx (PDB code: $1 \mathrm{MXT}$ ) conformation A, closed state; (B) ChOx (PDB code: 1MXT) conformation B, open state; (C) AnGOx (PDB code: 1CF3); (D) PaGOx (PDB code: 1GPE). Structure visualization was conducted using the PyMOL Molecular Graphics System, Version 2.2.3 Schrödinger, LLC. Tunnel visualization was performed for (A) and (B) by the PyMOL plugin CAVER 3.0.1. [51]. The starting point was FAD N5 and only the minimum probe radius was changed from the default value to $1.2 \AA$.

Schwander et al. reported the conversion of (2S)-methylsuccinyl-CoA dehydrogenase (MCD) into oxidase and utilized it in the carbon dioxide fixation pathway in vitro to avoid the rate-limiting step of the crotonyl-CoA/ethylmalonyl-CoA/hydroxybutyryl-CoA (CETCH) cycle [44]. In this cycle, 17 enzyme reaction networks, including MCD, can convert carbon dioxide into glyoxylate; but MCD requires an external electron acceptor, such as ferrocenium, to achieve high carbon dioxide fixation efficiency. Therefore, the MCD reaction is the rate-limiting step of this cycle, and the authors tried to convert MCD into an oxidase. The MCD Trp315Phe/Thr317Gly/Glu377Asn mutant exhibited oxidase activity, and the $\mathrm{CETCH}$ cycle efficiency was increased without the addition of an artificial electron acceptor. A more detailed enzymatic study was reported by Burgener et al., who discussed that Thr317 of this enzyme played a key role as a dioxygen gatekeeper on the Si-side of the isoalloxazine ring [45]. As a result of site-directed mutagenesis of Thr317Gly, the oxidase activity was increased by removing the bulky amino acid side chain located on the considered oxygen reaction site. This enzyme is a member of the acyl-CoA oxidoreductase (ACO) family, and this family of enzymes accommodates the substrate on the Re-side of the isoalloxazine ring (Figure 2C). Considering the differences in the VAO and ACO family enzymes structures and oxygen uptake routes, the engineering of the cavity in the vicinity of the isoalloxazine ring is useful as a versatile method. Although structural information of the VAO and ACO family showing possible interaction with molecular oxygen is not currently available, the prediction of the structures with oxygen, based on the combination of homology modeling and computational simulation, will provide great perspectives for future engineering research [52].

In addition, Tremey et al. replaced the nonpolar Val residue near FAD of PaGOx with a polar Ser residue [30]. Although wild-type PaGOx showed differences in the $K_{\mathrm{m}}$ value for ferrocenemethanol (FM) in the presence or absence of oxygen due to the competition of oxygen and FM in the oxidative half-reaction of PaGOx, the Val564Ser mutant showed almost the same $K_{\mathrm{m}}$ value for FM in the same experiment in both the presence and absence of oxygen. PaGOx Val564Ser exhibited a decreased 
reactivity for oxygen at low concentrations of glucose and a mitigated oxygen interference effect on the electrode incorporated in an osmium polymer. This result indicated that the polarity alteration around flavin may change the reactivity for oxygen. However, Gutierrez et al. mutated the same position of AnGOx (Val560) in a random mutagenesis study prior to the work of Tremey et al. and succeeded in decreasing the activity for oxygen and increasing the reactivity for the mediator, and the authors discussed the perturbation of the catalytic hydrogen-bonding network [31]. These results indicated that engineering of a cavity in the vicinity of flavin alters the oxidative half-reaction of oxidase with oxygen.

The third category focuses on the oxygen-accessible pathway from external enzymes to the vicinity of flavin [46-49]. Saam et al. reported the study of D-amino acid oxidase (DAO) by identifying the oxygen diffusion channel from the solvent to the flavin and oxygen high-affinity sites around flavin using molecular dynamics simulations and implicit ligand sampling methods [47]. Gly52, which is located in an oxygen high-affinity site on the Si-side of flavin, was substituted with Val to occupy this site and to obstruct oxygen access. The DAO Gly52Val mutant showed a more than 100 -fold decrease in the reactivity for oxygen, and without loss of catalytic reactivity in the reductive half-reaction. Since the substrate was recognized and oxidized on the Re-side of the isoalloxazine ring, a proton relay system based on a hydrogen-bonding network between amino acids around FAD was proposed. This system relayed protons from the substrate on the Re-side to oxygen on the Si-side of FAD; thus, the Gly52Val mutant was considered to disrupt the proton relay system in DAO (Figure 2D). Kim et al. reported the engineering of fructosyl amino acid oxidase (FAOx) from Pichia sp. N1-1 and amadoriase II from Aspergillus fumigatus to construct enzymes with decreased oxidase activity while retaining dye-mediated dehydrogenase activity [37]. The authors introduced mutations at residues composing the putative proton relay system of FAOx, focusing on the structural similarity of FAOx and DAO [47]. As a result, the FAOx Asn47Ala mutant and amadoriase II Asn52Ala mutant showed a drastic decrease in oxidase activity and maintained dye-mediated dehydrogenase activity. The authors also reported the engineering of fructosyl peptidyl oxidase (FPOx) from Phaeosphaeria nodorum. Compared with the wild-type, the FPOx Asn56Ala mutant showed an oxidase activity $V_{\max }$ value of $18 \%$ and a dye-mediated dehydrogenase activity $V_{\max }$ value of $233 \%$ [38]. The FPOx Asn56Ala mutant decreased the oxygen interference effect on the electrochemical system with an artificial electron mediator compared with the wild-type. Shimasaki et al. reported the X-ray structures of FPOx wild-type and Asn56Ala mutant [53], revealing that the main reason for the alteration of electron acceptor preference toward oxygen was due to the formation of novel hydrogen bonds which might eliminate the accessibility of oxygen toward the short pathway, thereby resulting in a drastic decrease in oxidase activity compared with dye-mediated dehydrogenase activity.

Hiraka et al. predicted the oxygen-accessible pathway in lactate oxidase (LOx), an FMN oxidoreductase, and attempted to block this pathway by amino acid substitution to decrease the oxidative half-reaction with oxygen (Figure 4) $[48,49]$. Aerococcus viridans LOx (AvLOx) mutants decreased oxidase activity drastically (only 1.0\% that of wild-type) but retained dye-mediated dehydrogenase activity ( $110 \%$ that of wild type) without any change in the substrate specificity and thermal stability. The AvLOx Ala96Leu mutant also mitigated the effect of oxygen interference on the electrochemical enzyme sensor employing an artificial electron acceptor. This was the first case of altering the reactivity for oxygen in the oxidative half-reaction in an $\alpha$-hydroxy acid oxidoreductase (HAO) family, which is an FMN-dependent enzyme and has a $(\beta / \alpha)_{8}$ TIM barrel fold, a completely different conformation to that of FAD-dependent enzymes (Figure 2E). 

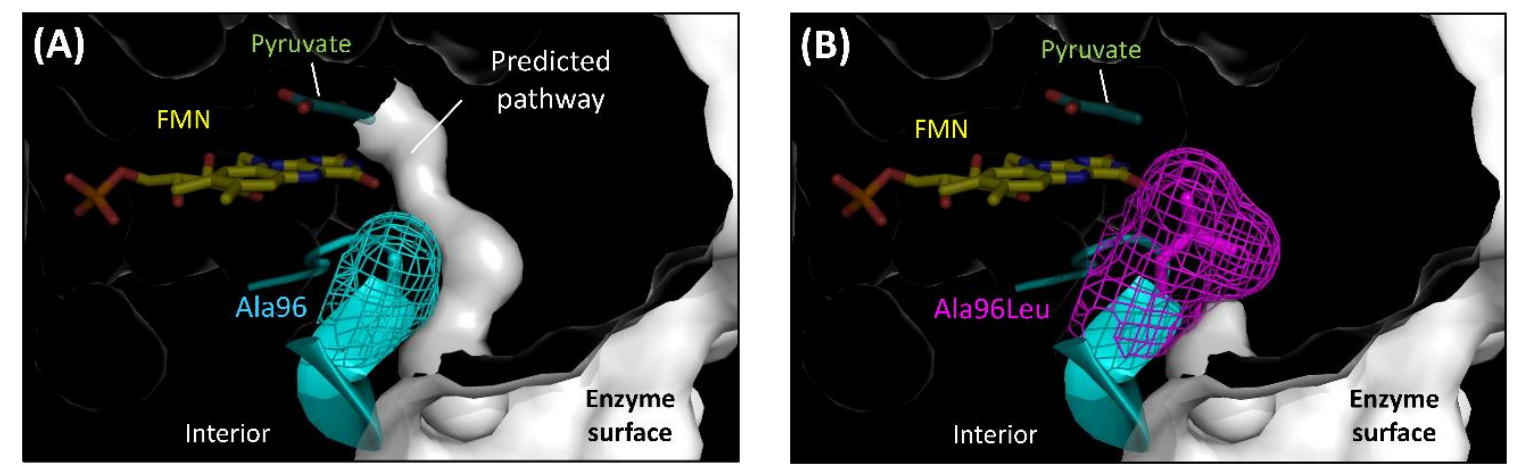

Figure 4. Obstruction of the predicted oxygen-accessible pathway in the AvLOx structure. (A) Wild type LOx from Aerococcus viridans. (PDB code: 2E77) (B) AvLOx Ala96Leu mutant. Structure visualization and mutation were conducted using the PyMOL Molecular Graphics System, Version 2.2.3 Schrödinger, LLC and its mutagenesis wizard. Tunnel visualization was performed by the PyMOL plugin CAVER 3.0.1. [51], the starting point was FMN C4a, and only the minimum probe radius was changed from default value to $0.85 \AA$.

These studies suggested that the third category, engineering of oxygen-accessible pathways, will be available for several family enzymes to engineer the reactivity for oxygen.

\section{Engineering of the Preference for Artificial Electron Acceptors}

Flavin-dependent oxidases and dehydrogenases utilize a variety of artificially synthesized electron acceptors, such as organic (e.g., quinone, viologen, and phenazine derivatives), inorganic (e.g., complex of iron, cobalt, and ruthenium), and metal-organic (e.g., osmium polymers and ferrocene polymers) compounds [2]. In the commercially available enzyme sensors for glucose, lactate and cholesterol, and in academic research about biosensors and biofuel cells, varieties of artificial electron acceptors were used as mediators between flavin-dependent oxidases/dehydrogenases and electrodes. Considering the practical application of biosensors and biofuel cells, artificial electron acceptors with high stability and with low redox potential have been preferably utilized, such as hexaammineruthenium and naphthoquinone [54,55]. However, the availability of artificial electron acceptors depends on the type of flavin-dependent oxidase or dehydrogenase, which demonstrate electron acceptor preferences. Therefore, the improvement of specificities or sensitivities toward these artificial electron acceptors is strongly desired. Pioneering research by Dixon summarized the electron acceptor specificity of flavins and flavoproteins in 1971 [56-58]. Although free reduced flavin can utilize and is oxidized by all the commonly used electron acceptors, the reduced flavin bound in proteins showed electron acceptor specificities depending on the proteins. With increasing demand for the use of varieties of artificial electron acceptors in electrochemical enzyme sensors, alteration of the electron acceptor preferences of flavin-dependent oxidoreductases are also increasing. Table 2 summarizes the representative studies reporting the investigation and engineering of artificial electron acceptor preferences. Four flavin-dependent oxidases and two dehydrogenases were reported, and their preference toward electron acceptors was changed by amino acid substitutions. These studies are categorized into three different approaches: (1) engineering of the charge at the residues around the substrate entrance, (2) engineering of a cavity in the vicinity of flavin, and (3) decreasing the glycosylation degree of enzymes. 
Table 2. Engineering approaches to alter the preferences of flavin-dependent oxidases and dehydrogenases for artificial electron acceptors.

\begin{tabular}{|c|c|c|c|c|c|c|}
\hline $\begin{array}{l}\text { Enzyme } \\
\text { (Source) }\end{array}$ & $\begin{array}{c}\text { Family } \\
\text { (EC: Number) }\end{array}$ & Co-Factor & Mutation Site & Mutated Position & Effects of Mutation & Reference \\
\hline \multicolumn{7}{|c|}{ (1) Engineering of surface residue around the substrate entrance } \\
\hline $\begin{array}{c}\text { Glucose oxidase } \\
\text { (Penicillium amagasakiense) }\end{array}$ & $\begin{array}{c}\text { GMC } \\
\text { (EC: } 1.1 .3 .16)\end{array}$ & FAD & K424E & Surface charged residue & $\begin{array}{l}\text { Increased reactivity } \\
\text { for osmium polymer }\end{array}$ & [59] \\
\hline $\begin{array}{l}\text { Glucose oxidase } \\
\text { (Aspergillus niger) }\end{array}$ & $\begin{array}{c}\text { GMC } \\
\text { (EC: } 1.1 .3 .16)\end{array}$ & FAD & D416A, D416H & Surface charged residue & $\begin{array}{l}\text { Decreased reactivity } \\
\text { for hexaammineruthenium (III) }\end{array}$ & [55] \\
\hline $\begin{array}{l}\text { Glucose dehydrogenase } \\
\text { (Aspergillus flavus) }\end{array}$ & $\begin{array}{c}\text { GMC } \\
(\text { EC: } 1.1 .5 .9)\end{array}$ & FAD & $\mathrm{H} 403 \mathrm{D}$ & Surface charged residue & $\begin{array}{l}\text { Increased reactivity } \\
\text { for hexaammineruthenium (III) }\end{array}$ & [55] \\
\hline \multicolumn{7}{|c|}{ (2) Engineering of a cavity in the vicinity of flavin } \\
\hline $\begin{array}{l}\text { Glucose oxidase } \\
\text { V7 mutant } \\
\text { (Aspergillus niger) }\end{array}$ & $\begin{array}{c}\text { GMC } \\
(\mathrm{EC}: 1.1 .3 .16)\end{array}$ & FAD & I414M, I414Y & Vicinity of FAD & $\begin{array}{l}\text { Increased reactivity for quinone } \\
\text { diamine based electron acceptors }\end{array}$ & [60] \\
\hline $\begin{array}{l}\text { Cytokinin oxidase } \\
\text { (Zea mays) }\end{array}$ & $\begin{array}{c}\mathrm{VAO} \\
\text { (EC: } 1.5 .99 .12)\end{array}$ & FAD (covalent) & D169E, L492A & Vicinity of FAD & $\begin{array}{l}\text { Increased reactivity for } \\
\text { several artificial electron acceptors }\end{array}$ & [61] \\
\hline $\begin{array}{l}\text { L-lactate oxidase } \\
\text { (Aerococcus viridans) }\end{array}$ & $\begin{array}{c}\text { HAO } \\
\text { (EC: } 1.1 .3 .15)\end{array}$ & FMN & A95G & Vicinity of FMN & $\begin{array}{c}\text { artificial electron acceptor } \\
\text { Decreased substrate specificity }\end{array}$ & [62] \\
\hline \multicolumn{7}{|c|}{ (3) Decreasing the glycosylation degree of the enzyme } \\
\hline $\begin{array}{l}\text { Pyranose dehydrogenase } \\
\quad \text { (Agaricus meleagris) }\end{array}$ & $\begin{array}{c}\text { GMC } \\
\text { (EC: } 1.1 .99 .29)\end{array}$ & FAD (covalent) & N75G, N175Q, N252Q & Glycosylation site & $\begin{array}{l}\text { Decreased glycosylation degree } \\
\text { Increased reactivity for osmium polymer } \\
\text { Decreased thermal stability }\end{array}$ & {$[63,64]$} \\
\hline
\end{tabular}


The first category was specifically focused on the charge proximal to the substrate entrance pocket of enzymes belonging to the GMC oxidoreductase family, considering that the charge of artificial electron acceptors can possibly result in electrostatic repulsion with enzymes [58,59]. Suraniti et al. attempted to improve the current densities of enzymatic anodes constructed with PaGOx and an osmium polymer [60]. The osmium complex is a positively charged redox electron acceptor. Therefore, the authors reported the substitution of a negatively charged amino acid residue into a positively charged amino acid residue positioned around the substrate entrance. As a result, the PaGOx Lys424Glu mutant showed a 2.4-fold higher current density than wild-type PaGOx, when osmium polymer was used as the electron acceptor. This research group combined the PaGOx Lys424Glu mutant and Val564Ser mutant to obtain a higher response current density without an oxygen interference effect [30]. Okurita et al. reported an alteration of the preference toward the positively charged electron acceptor, hexaammineruthenium(III), of glucose dehydrogenase derived from Aspergillus flavus (AfGDH) and AnGOx [59]. AfGDH could not utilize hexaammineruthenium(III) as the electron acceptor, whereas AnGOx could. Comparing the 3D structures of AfGDH and AnGOx, AnGOx has a negatively charged amino acid (Asp416) on the substrate entrance pocket, but AfGDH has a positively charged amino acid (His430), which corresponds to Asp416 of AnGOx (Figure 5). A single amino acid substitution of AfGDH, His430Asp and His430Glu, showed a drastic increase in enzyme activity using hexaammineruthenium(III) as the electron acceptor. In contrast, AnGOx Asp416His or Asp416Ala amino acid substitution almost eliminated enzyme activity using hexaammineruthenium(III) as the electron acceptor. These results demonstrated that charged residues around the substrate entrance pocket were responsible for determining the electron acceptor preference.
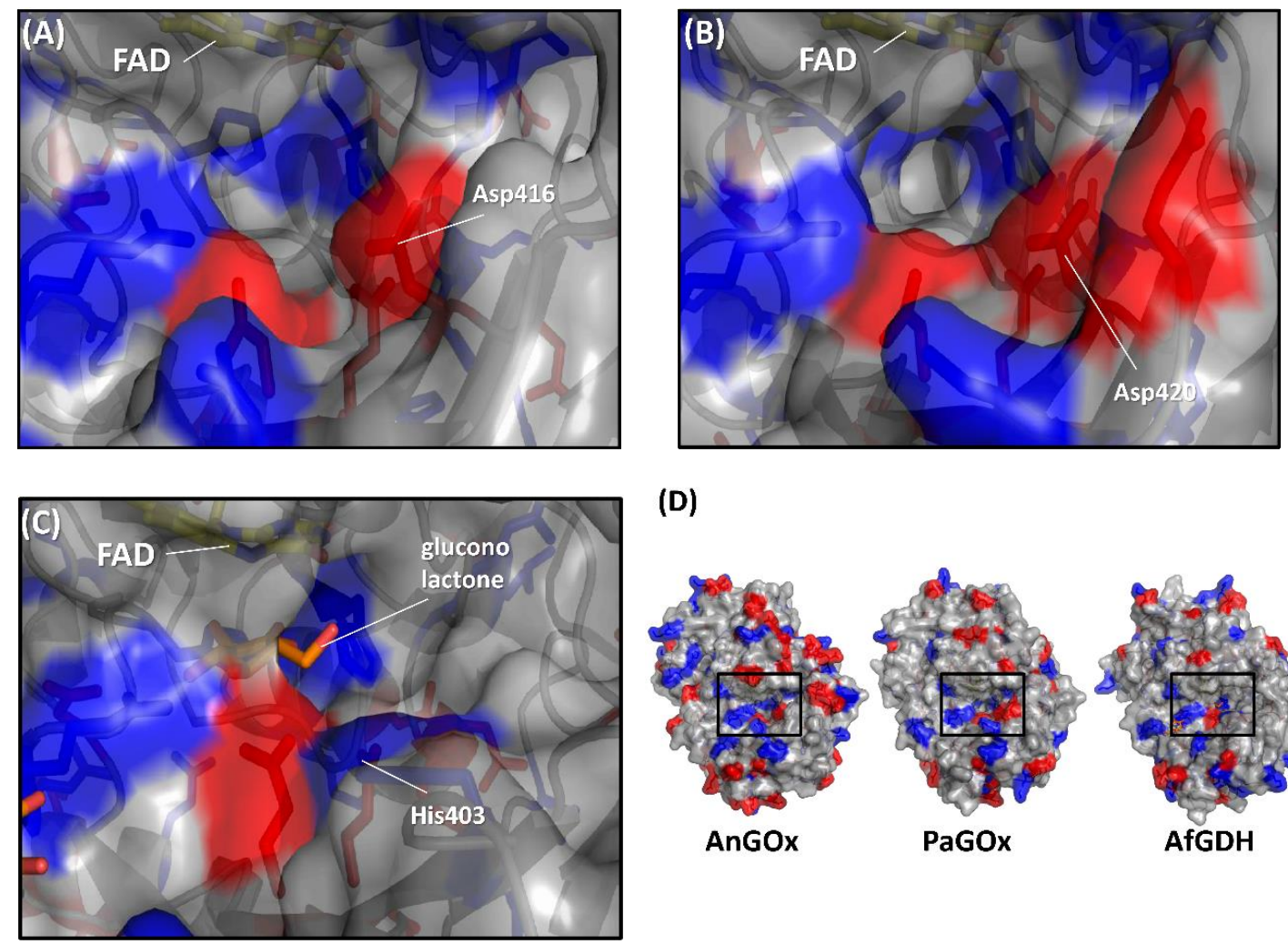

(D)


Figure 5. Comparison of the surface charge around the substrate entrance of (A) AnGOx (PDB code: 1CF3), (B) PaGOx (PDB code: 1GPE), and (C) AfGDH (PDB code: 4YNU). (D) Whole structure of these enzymes, and black squares show the substrate entrance. The red colored region shows the negatively charged residue, and the blue region shows the positively charged residue. Structure visualization was conducted using the PyMOL Molecular Graphics System, Version 2.2.3 Schrödinger, LLC. 
The second category focused on the amino acid residue in the vicinity of flavin [60-62]. Yorita et al. focused on AvLOx and planned to convert it into lactate monooxygenase (LMO). LOx Ala95, which is located in front of FMN N5, was substituted for Gly, considering that the corresponding residue of LMO was Gly [65]. However, AvLOx Ala95Gly was not turned into LMO, but the substrate specificity was changed from L-lactate to long-chain $\alpha$-hydroxy acids instead. Stoisser et al. reinvestigated the AvLOx Ala95Gly mutant, revealing that the mutation affected not only reductive half-reaction but also oxidative half-reaction [62]. LOx Ala95Gly mutation changed $k_{\mathrm{ox}}$ values with various artificial electron acceptors, which was not dependent on redox potential of the acceptors. The authors concluded that the LOx Ala95Gly mutant removed the steric bulk of the alanine side chain and caused a change in the electron acceptor specificity. This result also suggested that the electron acceptors enter the flavin vicinity as well as the substrate.

The third category focused on the correlation of glycosylation and enzyme electron acceptor preferences. The representative approach is the removal of glycosylation moieties of glycosylated flavin-dependent oxidases or dehydrogenases by chemical or endoglycosidase treatment. The deglycosylated GOx [66], GDH [67], PDH [68-70], and CDH [71] were immobilized on electrodes with osmium polymers and showed higher current density than glycosylated enzymes after addition of each substrate. The removal of the glycan shell contributed to the access of the redox polymer toward the active site of enzymes. However, these deglycosylation treatments are time-consuming and costly [63]. An alternative approach was performed with pyranose dehydrogenase (PDH) from Agaricus meleagris which is a glycosylated enzyme. The PDH crystal structure was analyzed [72], and the N-glycosylated site was also determined [68]. The non-glycosylated mutants of PDH were investigated for their electrochemical properties, compared with those with glycosylation using osmium polymer as the electron mediator. Yakovleva et al. reported that a number of A. meleagris PDHs, exhibiting different degrees of glycosylation, were produced using site-directed mutagenesis and electrochemically characterized [63]. They prepared Asn75Gly, Asn175Gln, Asn75Gly/Asn175Gln, and Asn75Gly/Asn175Gln/Asn252Gln PDH mutants. These mutants lacked glycosylated asparagine (N) residues and were expressed as enzymes in Pichia pastoris that lack part of the glycosyl moiety. Enzyme electrodes with PDH mutants were constructed together with various osmium polymers. As a result of flow-injection amperometry analyses, the Asn75Gly/Asn175Gln double mutant showed the highest current density using Os(dmbpy)-PVI and Os(bpy)-PVI; the Asn75Gly/Asn175Gln/Asn252Gln triple mutant indicated the highest current density with Os(dmobpy)-PVI. These results demonstrated that PDH mutants with fewer glycosylation moieties showed higher electron transfer efficiency with external electron acceptors, probably because the active site was more accessible to the osmium polymer, and electron transfer became faster. Although less glycosylated PDH mutants showed lower thermal stability due to the decreased glycosylation degree [64], the mutagenesis approach seems to be more practical than using deglycosylation treatments for alteration of the electron acceptor preference of glycosylated enzymes.

\section{Conclusion}

With increasing demands for the use of flavin-dependent oxidases and dehydrogenases for electrochemical applications, the investigation and engineering of the oxidative half-reaction of these enzymes have been increasing in significance. There have been two approaches in the studies of the oxidative half-reaction of flavin-dependent oxidases and dehydrogenases: engineering of the oxidative half-reaction with oxygen, and engineering of the preference for artificial electron acceptors.

Pioneering challenges have been reported to create dehydrogenases from oxidases to solve the inherent problem of oxidase-utilizing enzyme-based assays and electrochemical sensing systems employing artificial electron acceptors, where the competition of oxygen and artificial electron acceptors resulted in the inaccurate results. These challenges to engineering oxidative half-reactions with oxygen are categorized into the following approaches: (1) mutation to the putative residues that compose the 
cavity where oxygen may be located, (2) investigation of the locations where the reaction with oxygen may take place, and (3) investigation of possible oxygen access routes to the isoalloxazine ring.

The demand for the use of a variety of artificial electron acceptors in electrochemical enzyme sensors triggered research to alter the preference of electron acceptors of flavin-dependent oxidoreductases. The studies to engineer the preference of artificial electron acceptors are categorized into three different approaches: (1) engineering of the charge at the residues around the substrate entrance, (2) engineering of a cavity in the vicinity of flavin, and (3) decreasing the glycosylation degree of enzymes.

Among these approaches, introducing a mutation to the possible oxygen access route to the isoalloxazine ring represents the most versatile and effective strategy to create dehydrogenase from oxidase. To alter the preference of artificial electron acceptors, changing the charge in the vicinity where the electron acceptor is accessible will be most relevant, considering the charge of electron acceptors.

Alteration of electron acceptor preferences of flavin-dependent oxidases and dehydrogenases is an attractive approach in enzyme engineering, not only to elucidate the important amino acid residues for recognizing electron acceptors, but also to extend the future potential applications of existing well-characterized enzymes, such as GOx and LOx, for novel applications and transducers being developed to achieve high performance bioelectrochemical devices.

Author Contributions: Writing, editing, and original draft preparation, K.H.; writing and conceptualization; W.T.; supervision, conceptualization, writing, editing, and review, K.S. All authors have read and agreed to the published version of the manuscript.

Acknowledgments: K.H. was financially supported by the Nakatani Foundation for Advancement of Measuring Technologies in Biomedical Engineering.

Conflicts of Interest: The authors declare no conflict of interest.

\section{Abbreviations}

\begin{tabular}{ll} 
ACO & Acyl-CoA oxidase \\
AfGDH & Glucose dehydrogenase from Aspergillus flavus \\
AnGOx & Glucose oxidase from Aspergillus niger \\
AvLOx & L-lactate oxidase from Aerococcus viridans \\
BBE & berberine bridge enzyme \\
ChOx & Cholesterol oxidase \\
DAO & D-amino acid oxidase \\
DET & Direct electron transfer \\
FAD & Flavin adenine dinucleotide \\
FAOx & Fructosyl amino acid oxidase \\
FM & Ferrocene methanol \\
FMN & Flavin mononucleotide \\
FPOx & Fructosyl peptide oxidase \\
GMC & Glucose-methanol-choline \\
GOx & Glucose oxidase \\
HAO & $\alpha$-hydroxy acid oxidase \\
LMO & Lactate monooxygenase \\
LOx & L-lactate oxidase \\
MCD & (2S)-methylsuccinyl-CoA dehydrogenase \\
PDB & Protein data bank \\
PDH & Pyranose 2-dehydrogenase \\
PaGOx & Glucose oxidase from Penicillium amagasakiense \\
VAO & Vanillyl alcohol oxidase \\
& \\
\hline
\end{tabular}

\section{References}

1. Romero, E.; Gómez Castellanos, J.R.; Gadda, G.; Fraaije, M.W.; Mattevi, A. Same substrate, many reactions: Oxygen activation in flavoenzymes. Chem. Rev. 2018, 118, 1742-1769. [CrossRef] [PubMed] 
2. Heller, A.; Feldman, B. Electrochemical glucose sensors and their applications in diabetes management. Chem. Rev. 2008, 108, 2482-2505. [CrossRef] [PubMed]

3. Martens, N.; Hindle, A.; Hall, E.A.H. An assessment of mediators as oxidants for glucose oxidase in the presence of oxygen. Biosens. Bioelectron. 1995, 10, 393-403. [CrossRef]

4. Trampitsch, C.; Slavica, A.; Riethorst, W.; Nidetzky, B. Reaction of Trigonopsis variabilis D-amino acid oxidase with 2,6-dichloroindophenol: Kinetic characterisation and development of an oxygen-independent assay of the enzyme activity. J. Mol. Catal. B Enzym. 2005, 32, 271-278. [CrossRef]

5. Kenausis, G.; Taylor, C.; Katakis, I.; Heller, A. 'Wiring' of glucose oxidase and lactate oxidase within a hydrogel made with poly(vinyl pyridine) complexed with [Os(4,4[prime or minute]-dimethoxy-2,2[prime or minute]-bipyridine) $2 \mathrm{Cl}]^{+} / 2^{+}$. J. Chem. Soc. Faraday Trans. 1996, 92, 4131-4136. [CrossRef]

6. Fagan, R.L.; Palfey, B.A. Flavin-dependent enzymes. In Comprehensive Natural Products II: Chemistry and Biology; Elsevier: Amsterdam, The Netherlands, 2010; Volume 7, pp. 37-113.

7. Dijkman, W.P.; de Gonzalo, G.; Mattevi, A.; Fraaije, M.W. Flavoprotein oxidases: Classification and applications. Appl. Microbiol. Biotechnol. 2013, 97, 5177-5188. [CrossRef]

8. Clark, L.C., Jr.; Lyons, C. Electrode systems for continuous monitoring in cardiovascular surgery. Ann. N. Y. Acad. Sci. 1962, 102, 29-45. [CrossRef]

9. Davis, J.B.; Yarbrough, H.F. Preliminary experiments on a microbial fuel cell. Science 1962, 137, $615-616$. [CrossRef]

10. Rasmussen, M.; Abdellaoui, S.; Minteer, S.D. Enzymatic biofuel cells: 30 years of critical advancements. Biosens. Bioelectron. 2016, 76, 91-102. [CrossRef]

11. Bollella, P.; Gorton, L. Enzyme based amperometric biosensors. Curr. Opin. Electrochem. 2018, 10, $157-173$. [CrossRef]

12. Ferri, S.; Kojima, K.; Sode, K. Review of glucose oxidases and glucose dehydrogenases: A bird's eye view of glucose sensing enzymes. J. Diabetes Sci. Technol. 2011, 5, 1068-1076. [CrossRef] [PubMed]

13. Yokoyama, K.; Tamiya, E.; Karube, I. Performance of an integrated biosensor composed of a mediated and an oxygen-based glucose sensor under unknown oxygen tension. Anal. Lett. 1989, 22, 2949-2959. [CrossRef]

14. Cass, A.E.; Davis, G.; Francis, G.D.; Hill, H.A.O.; Aston, W.J.; Higgins, I.J.; Plotkin, E.V.; Scott, L.D.; Turner, A.P. Ferrocene-mediated enzyme electrode for amperometric determination of glucose. Anal. Chem. 1984, 56, 667-671. [CrossRef] [PubMed]

15. Binyamin, G.; Heller, A. Stabilization of wired glucose oxidase anodes rotating at $1000 \mathrm{rpm}$ at $37^{\circ} \mathrm{C}$. J. Electrochem. Soc. 1999, 146, 2965-2967. [CrossRef]

16. Kleppe, K. The effect of hydrogen peroxide on glucose oxidase from Aspergillus niger. Biochemistry 1966, 5, 139-143. [CrossRef]

17. Turner, A.; Karube, I.; Wilson, G.S. Biosensors: Fundamentals and Applications, 1st ed.; Oxford University Press: Oxford, NY, USA, 1987; p. 770.

18. Loew, N.; Fitriana, M.; Hiraka, K.; Sode, K.; Tsugawa, W. Characterization of electron mediator preference of Aerococcus viridans-derived lactate oxidase for use in disposable enzyme sensor Strips. Sens. Mater. 2017, 29 , 1703-1711.

19. Loew, N.; Tsugawa, W.; Nagae, D.; Kojima, K.; Sode, K. Mediator preference of two different FAD-dependent glucose dehydrogenases employed in disposable enzyme glucose sensors. Sensors 2017, 17, 2636. [CrossRef]

20. Chaiyen, P.; Fraaije, M.W.; Mattevi, A. The enigmatic reaction of flavins with oxygen. Trends Biochem. Sci. 2012, 37, 373-380. [CrossRef]

21. Carro, J.; Ferreira, P.; Martínez, A.T.; Gadda, G. Stepwise hydrogen atom and proton Transfers in Dioxygen Reduction by aryl-alcohol oxidase. Biochemistry 2018, 57, 1790-1797. [CrossRef]

22. Sucharitakul, J.; Prongjit, M.; Haltrich, D.; Chaiyen, P. Detection of a C4a-hydroperoxyflavin intermediate in the reaction of a flavoprotein oxidase. Biochemistry 2008, 47, 8485-8490. [CrossRef]

23. Mallett, T.C.; Claiborne, A. Oxygen reactivity of an NADH oxidase C42S mutant: Evidence for a C(4a)peroxyflavin intermediate and a rate-limiting conformational change. Biochemistry 1998, 37, 8790-8802. [CrossRef] [PubMed]

24. Brondani, P.B.; Dudek, H.M.; Martinoli, C.; Mattevi, A.; Fraaije, M.W. Finding the switch: Turning a Baeyer-Villiger monooxygenase into a NADPH oxidase. J. Am. Chem. Soc. 2014, 136, 16966-16969. [CrossRef] 
25. Yoshida, H.; Sakai, G.; Mori, K.; Kojima, K.; Kamitori, S.; Sode, K. Structural analysis of fungus-derived FAD glucose dehydrogenase. Sci. Rep. 2015, 5, 13498. [CrossRef] [PubMed]

26. Horaguchi, Y.; Saito, S.; Kojima, K.; Tsugawa, W.; Ferri, S.; Sode, K. Construction of mutant glucose oxidases with increased dye-mediated dehydrogenase activity. Int. J. Mol. Sci. 2012, 13, 14149-14157. [CrossRef] [PubMed]

27. Horaguchi, Y.; Saito, S.; Kojima, K.; Tsugawa, W.; Ferri, S.; Sode, K. Engineering glucose oxidase to minimize the influence of oxygen on sensor response. Electrochim. Acta 2014, 126, 158-161. [CrossRef]

28. Chen, L.; Lyubimov, A.Y.; Brammer, L.; Vrielink, A.; Sampson, N.S. The binding and release of oxygen and hydrogen peroxide are directed by a hydrophobic tunnel in cholesterol oxidase. Biochemistry 2008, 47, 5368-5377. [CrossRef] [PubMed]

29. Kojima, K.; Kobayashi, T.; Tsugawa, W.; Ferri, S.; Sode, K. Mutational analysis of the oxygen-binding site of cholesterol oxidase and its impact on dye-mediated dehydrogenase activity. J. Mol. Catal. B Enzym. 2013, 88, 41-46. [CrossRef]

30. Tremey, E.; Stines-Chaumeil, C.; Gounel, S.; Mano, N. Designing an $\mathrm{O}_{2}$-insensitive glucose oxidase for improved electrochemical applications. ChemElectroChem 2017, 4, 2520-2526. [CrossRef]

31. Gutierrez, E.A.; Mundhada, H.; Meier, T.; Duefel, H.; Bocola, M.; Schwaneberg, U. Reengineered glucose oxidase for amperometric glucose determination in diabetes analytics. Biosens. Bioelectron. 2013, 50, 84-90. [CrossRef]

32. Brugger, D.; Krondorfer, I.; Shelswell, C.; Huber-Dittes, B.; Haltrich, D.; Peterbauer, C.K. Engineering pyranose 2-oxidase for modified oxygen reactivity. PLoS ONE 2014, 9, e109242. [CrossRef]

33. Brugger, D.; Sützl, L.; Zahma, K.; Haltrich, D.; Peterbauer, C.K.; Stoica, L. Electrochemical characterization of the pyranose 2-oxidase variant N593C shows a complete loss of the oxidase function with full preservation of substrate (dehydrogenase) activity. Phys. Chem. Chem. Phys. 2016, 18, 32072-32077. [CrossRef] [PubMed]

34. Finnegan, S.; Agniswamy, J.; Weber, I.T.; Gadda, G. Role of valine 464 in the flavin oxidation reaction catalyzed by choline oxidase. Biochemistry 2010, 49, 2952-2961. [CrossRef] [PubMed]

35. Carro, J.; Amengual-Rigo, P.; Sancho, F.; Medina, M.; Guallar, V.; Ferreira, P.; Martínez, A.T. Multiple implications of an active site phenylalanine in the catalysis of aryl-alcohol oxidase. Sci. Rep. 2018, 8, 8121. [CrossRef] [PubMed]

36. Hernández-Ortega, A.; Lucas, F.; Ferreira, P.; Medina, M.; Guallar, V.; Martínez, A.T. Modulating $\mathrm{O}_{2}$ reactivity in a fungal flavoenzyme involvement of aryl-alcohol oxidase PHE-501 contiguous to catalytic histidine. J. Biol. Chem. 2011, 286, 41105-41114. [CrossRef]

37. Kim, S.; Nibe, E.; Ferri, S.; Tsugawa, W.; Sode, K. Engineering of dye-mediated dehydrogenase property of fructosyl amino acid oxidases by site-directed mutagenesis studies of its putative proton relay system. Biotechnol. Lett. 2010, 32, 1123-1129. [CrossRef]

38. Kim, S.; Nibe, E.; Tsugawa, W.; Kojima, K.; Ferri, S.; Sode, K. Construction of engineered fructosyl peptidyl oxidase for enzyme sensor applications under normal atmospheric conditions. Biotechnol. Lett. 2012, 34, 491-497. [CrossRef]

39. Zhao, G.; Bruckner, R.C.; Jorns, M.S. Identification of the oxygen activation site in monomeric sarcosine oxidase: Role of Lys265 in catalysis. Biochemistry 2008, 47, 9124-9135. [CrossRef]

40. Zafred, D.; Steiner, B.; Teufelberger, A.R.; Hromic, A.; Karplus, P.A.; Schofield, C.J.; Wallner, S.; Macheroux, P. Rationally engineered flavin-dependent oxidase reveals steric control of dioxygen reduction. FEBS J. 2015, 282, 3060-3074. [CrossRef]

41. Sygmund, C.; Santner, P.; Krondorfer, I.; Peterbauer, C.K.; Alcalde, M.; Nyanhongo, G.S.; Guebitz, G.M.; Ludwig, R. Semi-rational engineering of cellobiose dehydrogenase for improved hydrogen peroxide production. Microb. Cell Fact. 2013, 12, 38. [CrossRef]

42. Krondorfer, I.; Lipp, K.; Brugger, D.; Staudigl, P.; Sygmund, C.; Haltrich, D.; Peterbauer, C.K. Engineering of pyranose dehydrogenase for increased oxygen reactivity. PLoS ONE 2014, 9, e91145. [CrossRef]

43. Leferink, N.G.; Fraaije, M.W.; Joosten, H.-J.; Schaap, P.J.; Mattevi, A.; van Berkel, W.J. Identification of a gatekeeper residue that prevents dehydrogenases from acting as oxidases. J. Biol. Chem. 2009, 284, 4392-4397. [CrossRef] [PubMed]

44. Schwander, T.; von Borzyskowski, L.S.; Burgener, S.; Cortina, N.S.; Erb, T.J. A synthetic pathway for the fixation of carbon dioxide in vitro. Science 2016, 354, 900-904. [CrossRef] [PubMed] 
45. Burgener, S.; Schwander, T.; Romero, E.; Fraaije, M.; Erb, T. Molecular basis for converting (2S)methylsuccinyl-CoA dehydrogenase into an oxidase. Molecules 2018, 23, 68. [CrossRef] [PubMed]

46. Salvi, F.; Rodriguez, I.; Hamelberg, D.; Gadda, G. Role of $\mathrm{f} 357$ as an oxygen gate in the oxidative half-reaction of choline oxidase. Biochemistry 2016, 55, 1473-1484. [CrossRef]

47. Saam, J.; Rosini, E.; Molla, G.; Schulten, K.; Pollegioni, L.; Ghisla, S. O2 Reactivity of flavoproteins dynamic access of dioxygen to the active site and role of a $\mathrm{H}+$ relay system in D-amino acid oxidase. J. Biol. Chem. 2010, 285, 24439-24446. [CrossRef]

48. Hiraka, K.; Kojima, K.; Lin, C.-E.; Tsugawa, W.; Asano, R.; La Belle, J.T.; Sode, K. Minimizing the effects of oxygen interference on 1-lactate sensors by a single amino acid mutation in Aerococcus viridans 1-lactate oxidase. Biosens. Bioelectron. 2018, 103, 163-170. [CrossRef]

49. Hiraka, K.; Kojima, K.; Tsugawa, W.; Asano, R.; Ikebukuro, K.; Sode, K. Rational engineering of Aerococcus viridans L-lactate oxidase for the mediator modification to achieve quasi-direct electron transfer type lactate sensor. Biosens. Bioelectron. 2020, 151, 111974. [CrossRef]

50. Lario, P.I.; Sampson, N.; Vrielink, A. Sub-atomic resolution crystal structure of cholesterol oxidase: What atomic resolution crystallography reveals about enzyme mechanism and the role of the FAD cofactor in redox activity. J. Mol. Biol. 2003, 326, 1635-1650. [CrossRef]

51. Chovancova, E.; Pavelka, A.; Benes, P.; Strnad, O.; Brezovsky, J.; Kozlikova, B.; Gora, A.; Sustr, V.; Klvana, M.; Medek, P.; et al. CAVER 3.0: A tool for the analysis of transport pathways in dynamic protein structures. PLoS Comput. Biol. 2012, 8, e1002708. [CrossRef]

52. Baron, R.; McCammon, J.A.; Mattevi, A. The oxygen-binding vs. oxygen-consuming paradigm in biocatalysis: Structural biology and biomolecular simulation. Curr. Opin. Struc. Biol. 2009, 19, 672-679. [CrossRef]

53. Shimasaki, T.; Yoshida, H.; Kamitori, S.; Sode, K. X-ray structures of fructosyl peptide oxidases revealing residues responsible for gating oxygen access in the oxidative half reaction. Sci. Rep. 2017, 7, 2790. [CrossRef] [PubMed]

54. Milton, R.D.; Hickey, D.P.; Abdellaoui, S.; Lim, K.; Wu, F.; Tan, B.; Minteer, S.D. Rational design of quinones for high power density biofuel cells. Chem. Sci. 2015, 6, 4867-4875. [CrossRef] [PubMed]

55. Okurita, M.; Suzuki, N.; Loew, N.; Yoshida, H.; Tsugawa, W.; Mori, K.; Kojima, K.; Klonoff, D.C.; Sode, K. Engineered fungus derived FAD-dependent glucose dehydrogenase with acquired ability to utilize hexaammineruthenium (III) as an electron acceptor. Bioelectrochemistry 2018, 123, 62-69. [CrossRef] [PubMed]

56. Dixon, $\mathrm{M}$. The acceptor specificity of flavins and flavoproteins. I. Techniques for anaerobic spectrophotometry. Biochim. Biophys. Acta Bioenerg. 1971, 226, 241-258. [CrossRef]

57. Dixon, M. The acceptor specificity of flavins and flavoproteins. II. Free flavins. Biochim. Biophys. Acta Bioenerg. 1971, 226, 259-268. [CrossRef]

58. Dixon, M. The acceptor specificity of flavins and flavoproteins. III. Flavoproteins. Biochim. Biophys. Acta Bioenerg. 1971, 226, 269-284. [CrossRef]

59. Suraniti, E.; Courjean, O.; Gounel, S.; Tremey, E.; Mano, N. Uncovering and redesigning a key amino acid of glucose oxidase for improved biotechnological applications. Electroanalysis 2013, 25, 606-611. [CrossRef]

60. Arango Gutierrez, E.; Wallraf, A.M.; Balaceanu, A.; Bocola, M.; Davari, M.D.; Meier, T.; Duefel, H.; Schwaneberg, U. How to engineer glucose oxidase for mediated electron transfer. Biotechnol. Bioeng. 2018, 115, 2405-2415. [CrossRef]

61. Kopečný, D.; Končitíková, R.; Popelka, H.; Briozzo, P.; Vigouroux, A.; Kopečná, M.; Zalabák, D.; Šebela, M.; Skopalová, J.; Frébort, I. Kinetic and structural investigation of the cytokinin oxidase/dehydrogenase active site. FEBS J. 2016, 283, 361-377. [CrossRef]

62. Stoisser, T.; Rainer, D.; Leitgeb, S.; Wilson, D.K.; Nidetzky, B. The Ala95-to-Gly substitution in Aerococcus viridans L-lactate oxidase revisited-structural consequences at the catalytic site and effect on reactivity with $\mathrm{O}_{2}$ and other electron acceptors. FEBS J. 2015, 282, 562-578. [CrossRef]

63. Yakovleva, M.E.; Gonaus, C.; Schropp, K.; Conghaile, P.Ó.; Leech, D.; Peterbauer, C.K.; Gorton, L. Engineering of pyranose dehydrogenase for application to enzymatic anodes in biofuel cells. Phys. Chem. Chem. Phys. 2015, 17, 9074-9081. [CrossRef] [PubMed]

64. Gonaus, C.; Maresch, D.; Schropp, K.; Conghaile, P.Ó.; Leech, D.; Gorton, L.; Peterbauer, C.K. Analysis of Agaricus meleagris pyranose dehydrogenase N-glycosylation sites and performance of partially nonglycosylated enzymes. Enzym. Microb. Technol. 2017, 99, 57-66. [CrossRef] [PubMed] 
65. Yorita, K.; Aki, K.; Ohkuma-Soyejima, T.; Kokubo, T.; Misaki, H.; Massey, V. Conversion of L-lactate oxidase to a long chain $\alpha$-hydroxyacid oxidase by site-directed mutagenesis of alanine 95 to glycine. J. Biol. Chem. 1996, 271, 28300-28305. [CrossRef] [PubMed]

66. Prévoteau, A.; Courjean, O.; Mano, N. Deglycosylation of glucose oxidase to improve biosensors and biofuel cells. Electrochem. Commun. 2010, 12, 213-215. [CrossRef]

67. Murata, K.; Akatsuka, W.; Sadakane, T.; Matsunaga, A.; Tsujimura, S. Glucose oxidation catalyzed by FAD-dependent glucose dehydrogenase within Os complex-tethered redox polymer hydrogel. Electrochim. Acta 2014, 136, 537-541. [CrossRef]

68. Yakovleva, M.E.; Killyéni, A.; Seubert, O.; Conghaile, P.Ó.; Macaodha, D.; Leech, D.; Gonaus, C.; Popescu, I.C.; Peterbauer, C.K.; Kjellström, S.; et al. Further insights into the catalytical properties of deglycosylated pyranose dehydrogenase from Agaricus meleagris recombinantly expressed in Pichia pastoris. Anal. Chem. 2013, 85, 9852-9858. [CrossRef] [PubMed]

69. Yakovleva, M.E.; Killyéni, A.; Ortiz, R.; Schulz, C.; MacAodha, D.; Conghaile, P.Ó.; Leech, D.; Popescu, I.C.; Gonaus, C.; Peterbauer, C.K.; et al. Recombinant pyranose dehydrogenase-A versatile enzyme possessing both mediated and direct electron transfer. Electrochem. Commun. 2012, 24, 120-122. [CrossRef]

70. Killyéni, A.; Yakovleva, M.E.; MacAodha, D.; Conghaile, P.Ó.; Gonaus, C.; Ortiz, R.; Leech, D.; Popescu, I.C.; Peterbauer, C.K.; Gorton, L. Effect of deglycosylation on the mediated electrocatalytic activity of recombinantly expressed Agaricus meleagris pyranose dehydrogenase wired by osmium redox polymer. Electrochim. Acta 2014, 126, 61-67. [CrossRef]

71. Shao, M.; Zafar, M.N.; Falk, M.; Ludwig, R.; Sygmund, C.; Peterbauer, C.K.; Guschin, D.A.; MacAodha, D.; Conghaile, P.Ó.; Leech, D.; et al. Optimization of a membraneless glucose/oxygen enzymatic fuel cell based on a bioanode with high coulombic efficiency and current density. ChemPhysChem 2013, 14, 2260-2269. [CrossRef]

72. Tan, T.C.; Spadiut, O.; Wongnate, T.; Sucharitakul, J.; Krondorfer, I.; Sygmund, C.; Haltrich, D.; Chaiyen, P.; Peterbauer, C.K.; Divne, C. The $1.6 \AA$ A crystal structure of pyranose dehydrogenase from Agaricus meleagris rationalizes substrate specificity and reveals a flavin intermediate. PLoS ONE 2013, 8, e53567. [CrossRef]

(C) 2020 by the authors. Licensee MDPI, Basel, Switzerland. This article is an open access article distributed under the terms and conditions of the Creative Commons Attribution (CC BY) license (http://creativecommons.org/licenses/by/4.0/). 